\title{
A Correlation Coefficients among Some Productive and Qualitive Traits in Onion Crop (Allium cepa L.)
}

\author{
Amer, M. Abdel Aziz ${ }^{1}$, Ismael A. A. Yaso ${ }^{2}$
}

\begin{abstract}
The present experimental work was conducted in the Farm of Nubaria Agricultural Research Station for the two successive winter seasons of 2011/2012 and 2012/2013 on onion crop to study the correlation coefficients among the characters of total yield, marketable yield, average bulb weight, days to maturity, plant height, number of leaves per plant, percentage of single bulbs, percentage of double bulbs, percentage of bolters, total soluble solids (TSS \%) and storage ability of bulbs. Results showed that correlation coefficients among characters were positive with days to maturity, plant height, number of leaves per plant, percentage of double bulbs, total soluble solids (TSS $\%)$ and storage ability of bulbs in both seasons while the correlation coefficients among characters were negative among total yield with percentage of bolters, marketable yield with storage ability of bulbs, percentage of single bulbs with percentage of bolters and percentage of bolters with total soluble solids (TSS \%) in the first season. Also, in the second season, the correlation coefficients among characters were found to be negative among marketable yield with percentage of bolters, average bulb weight with storage ability of bulbs and percentage of single bulbs with both percentage of double bulbs and percentage of bolters.
\end{abstract}

Keywords: Onion, correlation coefficients, bulb weight, Percentage of single bulbs

\section{INTRODUCTION}

Onion (Allium cepa L.) is one an important and specific crop cultivated all over the world. It is also used as avegatable, salad and has preservative and medecinal values. Onion grows in almost all the districts of Egypt as winter crop. The average yield / fed., in Egypt is still in need to be improved for facing the requirements of the local and world markets. Bulb weight is consedered as the most improvement component of both total and market able yield. Yield is a complex character, which is deponded on a number of agronomic characters and is highly influenced, as all quantitative trais, by many genetic factors as well as by environmental fluctuations (Rabinowitch and Brewster, 1990). Consequently, direct selection for yield can be misleading. So, to improve the yield via selection, knowledge of the nature of associations, total and marketable yield and its contributing characters is very essential. Estimate of correlation that exists among important bulb characters are useful in planing of breeding programs and evaluating breeding materials more efficiently. Besides, it facilitates the interpretation of results already obtained. Rahman et al. (2002) reported that bulb weight had significant positive correlation with plant height and no. of leaves/plant. Path analysis indicated that the plant height and no. of leaves/plant were the principle components (as adirect effect) of bulb weight.Thus, selecting plants for better plant type and other characters may lead to more improvements in onion yield.

Correlation coefficient analysis has been widely used in crop breeding to determine the nature of relationships between yield and its contributing components and to identify those components with significant effect on yield for potential use as selection criteria (Puri et al., 1982; Kang et al., 1983; Milligan et al., 1990; Zarei et al., 2012; Khalili et al., 2013a; Khalili et al., 2013b; Poursiahbidi et al., 2013b; Ahmadi et al., 2016).

The present work aims at:

(a) Studying correlation coefficients among the characters.

(b) Also, estimating the direct and indirect contributions of the studied traits on total yield.

\section{MATERIALS AND METHODS}

The present work was conducted in the Farm of Nubaria Agricultural Research Station for the two successive winter seasons of 2011/2012 and 2012/2013 on onion crop.

Twelve and ten genotypes of seedling were transferred and planted in $19^{\text {th }}$ December, 2011 and in $16^{\text {th }}$ December, 2012 in the first and the second growing seasons, respectively. The experimental plot size was 7 $\mathrm{m}^{2}$ (1/600 fed.). Each plot consisted of four ridges, 50 $\mathrm{cm}$ wide and $3.5 \mathrm{~m}$ long. Seedlings were planted in both sides of the ridge and spaced at $10 \mathrm{~cm}$. The fertilization and other agromic practices were carried out as usually done in the conventional onion field. A rondomized block design (RCBD) with four replicates was used to conduct both experiments of the two seasons. The tested genotypes of the first season were: Harla white and Hyb. 8 Hazera (forighn commercid cv.), TEYG, Ori Yellow and BAIA Periform (USA commerical cv.), Giza 20 XTEY and Giza 20 X Ori (the sixth selected generation), Bustan, Comosite 16, Comosite 13 Oblong,

${ }^{1}$ Genetic Resources Research Dept., Field crops research institute, ARC, Giza, Egypt.

${ }^{2}$ Onion Research Dept., Field crops research institute, ARC, Giza, Egypt. Received May 18, 2016, Accepted June 16, 2016 
Giza Red Bulk and Giza 20 Bulk (Egyptian lines). The tested genotypes of the second season were: Beta Alpha (An Europian Commercial cv.), Comosite 4 Globe and Comosite 18 (Egyptian lines), Gladalan Red (An Indian commercial cv.), Giza 20 (An Egyptian commercial cv.), 186 No Pink, Giza 6 M.DMR and Comosite 18 DMR (Egyptian lines).

During the two seasons, the following data were recorded:

Bulb yield: At harvest, all plants in each experimental plot were pulled and the following data were collected:

1. Total yield (Ton / Fed.): It was collected on the basis of the whole yield per experimental plot.

2. Marketable yield (Ton / Fed.): It was obtained from weight of only healthy single bulbs.

3. Average bulb weight (g): It was collected by dividing the total weight of single bulbs by the number of bulbs

4. Days to maturity: No. of days from transplanting date to maturity, based on the softening of bulb neck.

5. Plant height: It was measured after 120 days from transplanting.

6. Number of leaves per plant: It was taken after 120 days from transplanting.

7. Percentage of single bulbs: It was estimated by dividing number of single bulbs by the total number of bulbs per plot $\times 100$.

8. Percentage of double bulbs: It was estimated by dividing number of double bulbs by the total number of bulbs per plot $\times 100$.

9. Percentage of bolters: It was estimated by dividing number of bolters by the total number of bulbs per plot $\times 100$.

10. Total soluble solids (TSS \%): It includes mainly soluble sugars, amino acids and soluble minerals. It was determined using the hand refractor meter in the materials at the end of 6 months storing period.

11. Storage ability of bulbs: It was expressed by calculating the sprouted bulbs ratio of onion stored under common storage conditions for a period of six months.

\section{Statistical analysis}

Statistical analysis including the estimates of correlation coefficients was done according to Steel and Torrie (1960). Path coefficients analyses were done according to the method described by Dewey and $\mathrm{Lu}$ (1959).

\section{ESULTS AND DISCUSSION}

The listed results in Tables (1 and 2) elucidated the correlation coefficient between 11 characters during the two successive seasons of 2011/2012 and 2012/2013, respectively.

In the first season of 2011/2012, 11 traits were found to be significant or highly significant (Table1):

1. Total yield highly significant possitive association with marketable yield $\left(0.943^{* *}\right)$, average bulb weight $\left(0.946^{* *}\right)$, percentage of single bulbs $(0.422 * *)$, total soluble solids (TSS \%) $(0.682 * *)$ and storage ability of bulbs $\left(0.375^{* *}\right)$ and negative with percentage of bolters $(-0.400 * *)$,

2. Marketable yield proved to be postivelly and significantaly associated with total yield $\left(0.943^{* *}\right)$, average bulb weight $\left(0.996^{* *}\right)$ plant hight $\left(0.331^{*}\right)$ and days to maturity $\left(0.358^{*}\right)$. A highly significant negative association with storage ability of bulbs $(-0.363 *)$ is also noticed.

3. Average bulb weight was found to be significant positive association with Plant height $\left(0.313^{*}\right)$ and days to maturity $\left(0.355^{*}\right)$ and highly significant negative association with total soluble solids (TSS $\%)(649 * *)$ and storage ability of bulbs (374**)

4. Days to maturity was highly significant positive association with total soluble solids (TSS \%) $\left(0.546^{* *}\right)$ and torage ability of bulbs $(0.494 * *)$

5. Plant hight was significant positive association with number of leaves per plant $\left(0.294^{*}\right)$, and percentage of single bulbs $\left(0.298^{*}\right)$ and percentage of bolters $(0.33 *)$

6. Number of leaves per plant was found to be not significant association with percentage of single bulbs, percentage of double bulbs, percentage of bolters, percentage of bolters and Storage ability of bulb.

7. Percentage of single bulbs was height significant negative association with percentage of bolters $(-0.985 * *)$.

8. Percentage of double bulbs is not significant associated with all characters.

9. Percentage of bolters was significant negative association total soluble solids (TSS \%) $\left(-0.313^{*}\right)$.

10. Total soluble solids (TSS \%) was high significant positive association with storage ability of bulbs $(0.627 * *)$

In the second season of 2012/2013, the results presented in Table (2) indicated that 11 characters were found to be significant or highly significant. 


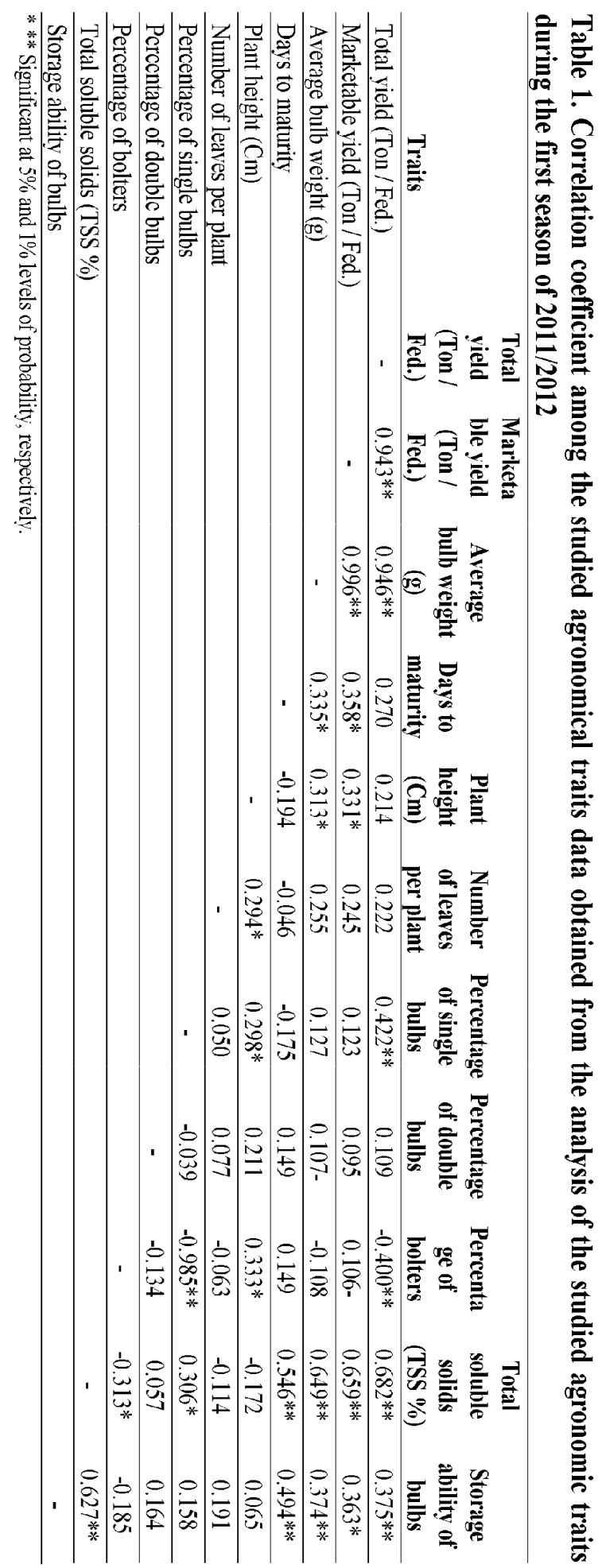




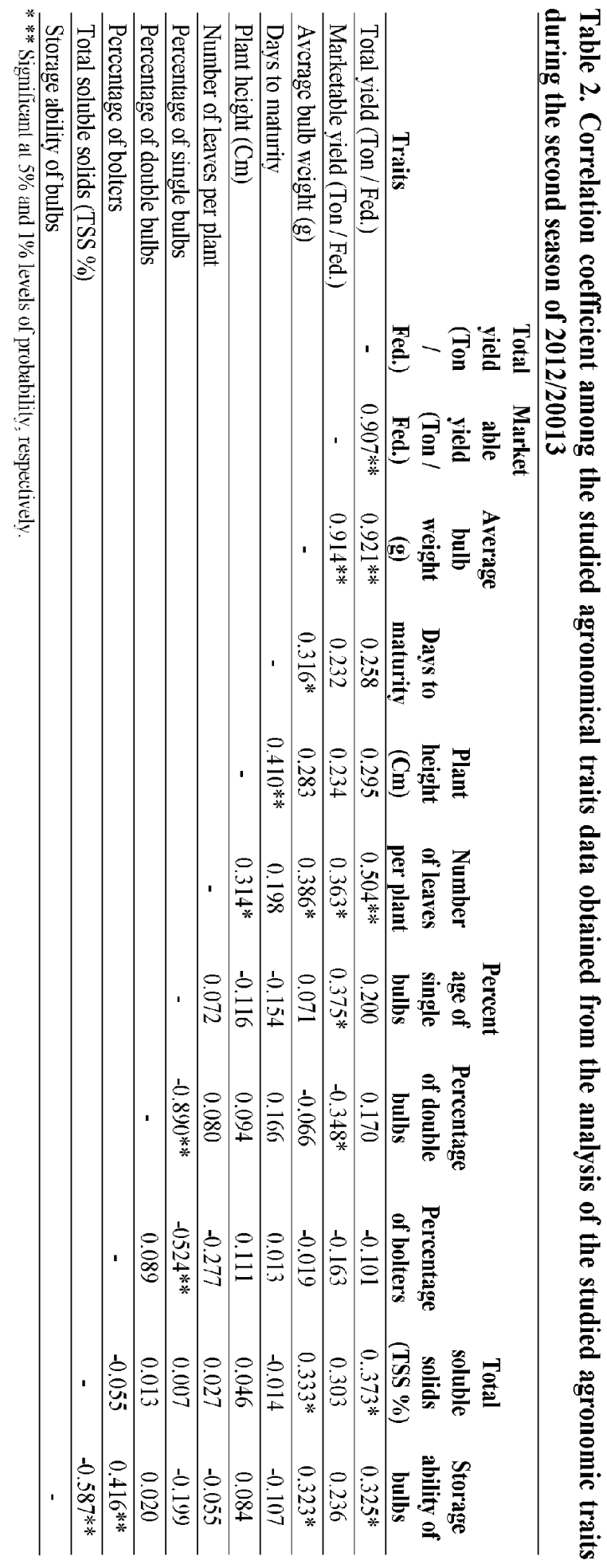


1. Total yield hight significant positive association with marketable yield $(0.907 * *)$, average bulb weight $\left(0.921^{* *}\right)$ and number of leaves per plant $\left(0.524^{* *}\right)$ and significant positive with storage ability of bulbs $\left(0.325^{*}\right)$ and total soluble solids (TSS \%) $(0.323 *)$

2. Marketable yield hight significant positive association with total yield $(0.907 * *)$ and Average bulb weight $(0.914 * *)$ and significant positive association with number of leaves per plant $\left(0.363^{*}\right)$ and percentage of single bulbs $\left(0.375^{*}\right)$ and significant negative association with percentage of double bulbs $(-0.348 *)$

3. Average bulb weight significant positive association with days to maturity $\left(0.316^{*}\right)$, number of leaves per plant $\left(0.386^{*}\right)$ and negative with storage ability of bulbs $\left(-0.323^{*}\right)$.

4. Days to maturity hight significant positive association with plant hight $\left(0.410^{* *}\right)$ and significant positive association with average bulb weight $\left(0.316^{*}\right)$

5. Plant hight highly significant positive association with days to maturity $\left(0.410^{* *}\right)$ and significant positive association with number of leaves per plant $(0.314 *)$

6. Number of leaves per plant was no significant association with Percentage of single bulbs, Percentage of double bulbs, percentage of bolters, Percentage of bolters and Storage ability of bulb.

7. Percentage of single bulbs was height significant negative association with percentage of double bulbs $(-0.890 * *)$ and percentage of bolters $(-0.524 * *)$

8. Percentage of double bulbs is not significant associated with all characters.

9. Percentage of is not significant associated with all characters.

10. Total soluble solids (TSS \%) was height significant positive association with storage ability of bulbs $(0.587 * *)$

These results were in accordance with those reported by Mohanty (2001 and 2002), Chema (2003) and Trivedi et al. (2006). Yaso (2007) who studied the phenotypic correlation and path coefficient analysis between bulb weight and various components that affect this trait in onion genotype and found that correlation were significant and positive between bulb weight and each of plant height and no. of leaves/plant in the both seasons of 2003/2004 and 2004/2005.

\section{REFERENCES}

Ahmadi, J, B. Vaezi and A.Pour-Aboughadareh 2016. Assessment of heritability and relationships among agronomic characters in grass pea (Lathyrus sativus L.) under rain field conditions. Biharean Biologist (in press).

Chema, K. L., A. Saeed and M.Habib 2003.Unidirectional and alternate pathway influences of some economic traits in onion (Allium cepa L.). International J. Agric. and Biology, 5(4):487-489.

Dewey, D. R. and K. H.Lu 1959. Acorrelation and path coeffocient analysis of component of crested wheat grass seed production. Agron. J., 51: 51-58.

Kang, M. S., J. D. Miller and P. Y. P.Tai 1983. Genetic and phenotypic path analyses and heritability in sugarcane. Crop Sci., 23: 643-647.

Khalili, M., A. R. Pour M. R. Aboughadareh, Naghavi and H.Naseri Rad 2013a. Path analysis of the relationships between seed yield and some of morphological traits in safflower (Carthamus tinctorius L.) under normal irrigation and rainfed conditions. Tech. J. Engineering Applied Sci., 3(15): 1692-1696.

Khalili, M., M. R. Naghavi; A. R. Pour Aboughadareh and H.Naseri Rad 2013b. Evaluation of relationships among grain yield and related traits in Maize (Zea mays L.) cultivars under drought stress. Int. J. Agronomy Plant Production, 4(6): 1251-1255.

Milligan, S. B., K. A. Gravois; K. P. Bischoff and F. A.Martin 1990. Crop effects on genetic relationships among sugarcane traits. Crop Sci., 30: 927-931.

Mohanty, B. K. 2001. Genetic variability, inter-relationship and path analysis in onion. J. Tropical Agric., 39: 17-20.

Mohanty, B. K. 2002. Genetic variability, inter-relationship and path analysis in onion. National J. Plant Improvement, 4(1):57-60.

Pour-Siahbidi, M. M., J. Hoseinzadeh, A. R. PourAboughadareh, A. R. Bazdar, H. Besati and H.Naseri Rad 2013b. Character association and path analysis of soybean (Glycine max L.) genotypes under water deficit stress, 3(10): 126-132.

Puri Y. P., CO. Qualset, W. A. Williams, M. B. Jones and M. W.Demment 1990. Evaluation of yield components as selection criteria in barley breeding.). Agronomy J., 82:1022-1024.

Rabinowitch, H. D. and J. L. Brewster 1990. Onions and allied Crops. Vol. I. Botany, physiology and genetics. CRC Press, Boca Raton, FL.

Rahman, M. A., S. R. Saha, M. A. Salam, A. S. M. H. Masum and S.S. Chowdhury 2002. Correlation and Path coefficient analysis in onion (Allium cepa L.). J. Biolo. Sci., 2(8): 533-534.

Steel, R. G. D. and J. H.Torrie 1960. Principles and procedures of statistics McGraw Hill Book Company, Inc. New Yourk. 
Trivedi, A. P., K. N. Dhumal and K. E.Lawande 2006. Estimates of heritability, genetic advance and correlation. Indian J. Gen. Plant Breed., 66(1): 59-60.

Yaso, I. A. A. 2007. Phenotypic correlation and path correlation analysis in some onion genotypes. Egypt. J. Plant Breed., 11(3): 299-306.
Zarei B., D.Kahrizi, A. R. Pour Aboughadareh and F.Sadeghi 2012. Correlation and path coefficient analysis for determining interrelationship among grain yield and related characters in corn hybrids (Zea mays L.). Int. J. Agricult. Crop Sci., 4(20): 1519-1522.

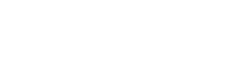

\section{تحليل التلازم بين بعض الصفات المحصولية والجودة في محصول البصل

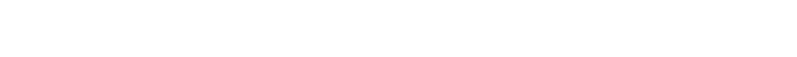

الصلبة الذائبة الكلية والقدرة التخزينية للأبصل ف فى ك ـلا

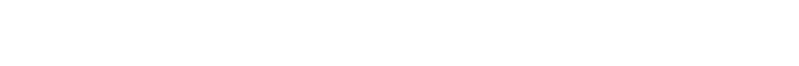

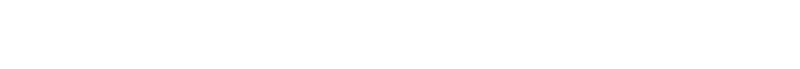

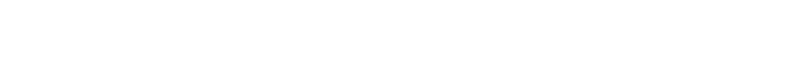

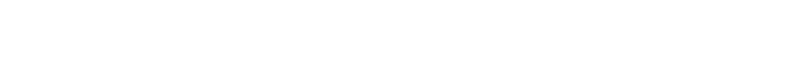

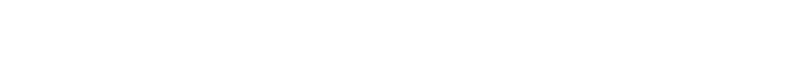

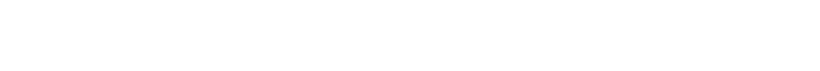

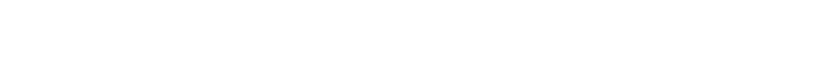

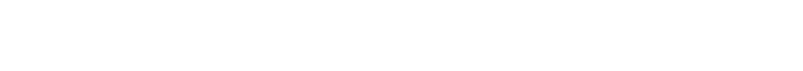
ونسبة الأبصل المزهرة.
لجريت التجربة الحالية فى مطة البح ـوث الزراعي مة

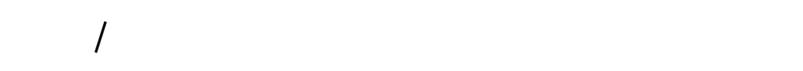

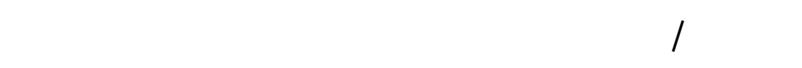

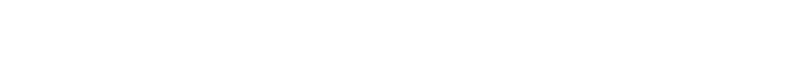

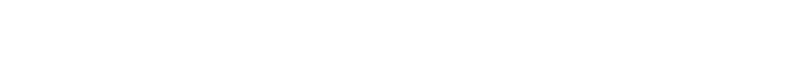

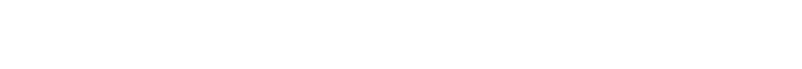

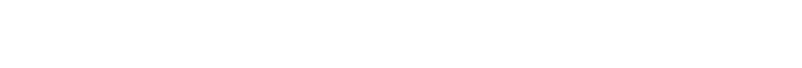

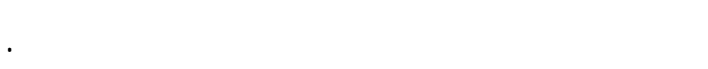

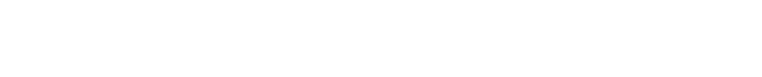

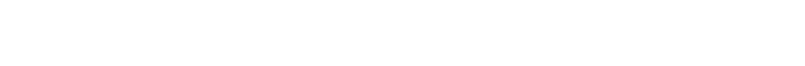

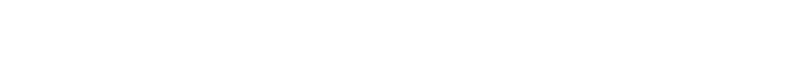

